\title{
Correction: X-chromosome-linked miR548am-5p is a key regulator of sex disparity in the susceptibility to mitochondria-mediated apoptosis
}

Paola Matarrese ${ }^{1}$, Paolo Tieri ${ }^{2,3}$, Simona Anticoli ${ }^{1}$, Barbara Ascione ${ }^{1}$, Maria Conte ${ }^{4,5}$, Claudio Franceschi ${ }^{6,7}$, Walter Malorni $\mathbb{1}^{1,8}$, Stefano Salvioli, ${ }^{4,5}$ and Anna Ruggieri ${ }^{1}$

\section{Correction to: Cell Death \& Disease} https://doi.org/10.1038/s41419-019-1888-3, published online 11 September 2019.

Since online publication of this article, the authors noticed that the Supplementary Tables S1-S8 were absent from the published version. The article has now been corrected to include these. The authors apologize for any inconvenience caused.

Published online: 04 November 2019

Correspondence: Stefano Salvioli (stefano.salvioli@unibo.it) or

Anna Ruggieri (anna.ruggieri@iss.it)

${ }^{1}$ Center for Gender Specific Medicine, Istituto Superiore di Sanità, viale Regina Elena 299, Rome, Italy

${ }^{2}$ CNR National Research Council, IAC Institute for Applied Computing, Via dei

Taurini 19, Rome, Italy

${ }^{3}$ Data Science Program, La Sapienza University of Rome, Rome, Italy

${ }^{4}$ Department of Experimental, Diagnostic and Specialty Medicine (DIMES),

University of Bologna, Bologna, Italy

5Interdepartmental Centre "L. Galvani" (CIG), University of Bologna, via San

Giacomo 12, 40126 Bologna, Italy

${ }^{6}$ IRCCS Istituto delle Scienze Neurologiche di Bologna, Via Altura 3, 40139

Bologna, Italy

7 Lobachevsky State University of Nizhny Novgorod, Nizhny Novgorod, Russia

${ }^{8}$ School of Mathematical, Physical and Natural Sciences and Faculty of

Medicine, University of Tor Vergata, Rome, Italy

These authors contributed equally: Paola Matarrese, Paolo Tieri

These authors contributed equally: Stefano Salvioli, Anna Ruggieri

Edited by M. Piacentini

(c) (i) Open Access This article is licensed under a Creative Commons Attribution 4.0 International License, which permits use, sharing, adaptation, distribution and reproduction in any medium or format, as long as you give appropriate credit to the original author(s) and the source, provide a link to the Creative Commons license, and indicate if changes were made. The images or other third party material in this article are included in the article's Creative Commons license, unless indicated otherwise in a credit line to the material. If material is not included in the article's Creative Commons license and your intended use is not permitted by statutory regulation or exceeds the permitted use, you will need to obtain permission directly from the copyright holder. To view a copy of this license, visit http://creativecommons.org/licenses/by/4.0/. 